DOI: https://doi.org/10.47405/mjssh.v6i9.1057

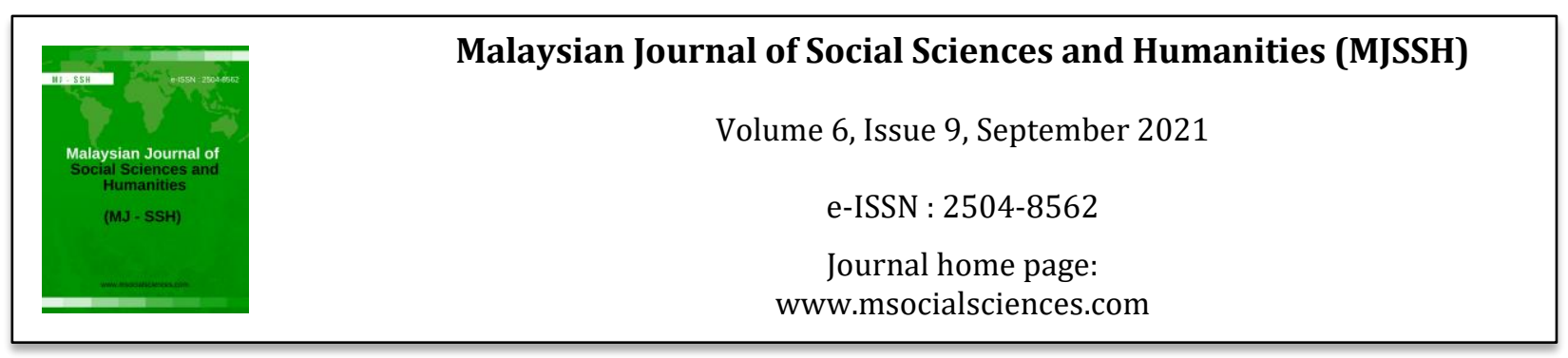

\title{
Barriers in Purchasing Organic Clothing Product Among Z Generation Women in Indonesia
}

\author{
Aisha Nur Shafira Putri ${ }^{1}$, Shimaditya Nuraeni ${ }^{1}$ \\ ${ }^{1}$ School of Business and Management, Bandung Institute of Technology, Indonesia \\ Correspondence: Aisha Nur Shafira Putri (aisha_nur@sbm-itb.ac.id)
}

\begin{abstract}
Nowadays, organic product demand seems to arise and many people start to change their lifestyle to using organic products. Ranging from organic food, organic personal care, organic crafts to organic fashion. There are various kinds of fashion products and one of them is organic clothing products. Organic clothes are clothes that mainly use organic fabrics that are made of natural fibers using natural materials. However, in Indonesia, it seems like there are still people who do not use this organic clothing product because of the skepticism or they do not have adequate knowledge about organic clothing products. It indicates that some barriers occur to consumers, so they haven't used organic clothing. Within this study, the researchers tried to analyze the barriers to purchasing organic clothing products among 166 women in the gen- $\mathrm{z}$ in Jabodetabek and Bandung with the use of Innovation Resistance Theory (IRT). The research was conducted using questionnaires and analyzed using Multiple Linear regression with SPSS Software. The results indicate that risk barrier and tradition barrier have positively and significantly affected organic clothing products purchase intention. These findings may be useful in developing business strategies for organic clothing SMEs in Indonesia, with a focus on the indicator aspect of risk barriers and traditional barriers.
\end{abstract}

Keywords: barriers, innovation resistance theory, organic, organic clothing product, purchase intention

\section{Introduction}

Nowadays, organic product demand seems to arise and many people start to change their lifestyle to using organic products. Many companies, governments, brands, and communities have started to meet the demand for organic products (Maheshwari \& Malhotra, 2011). People have started to be interested in modifying their lifestyle to use organic products, due to public awareness of the risks of synthetic materials, which are not only bad for health but also have a detrimental effect on the environment (Thompson, 2005). Ranging from organic food, organic personal care, organic crafts to organic fashion.

Talking about fashion, it was one of the biggest market industries, and the market itself can be valued at around 406 billion dollars and contribute 2 percent to the world's Gross Domestic Product (Fashionunited, 2017). Following statistical data from statista.com, revenue in the Fashion segment is projected to reach US $\$ 12,556 \mathrm{~m}$ in 2021 , and revenue is expected to show an annual growth rate (CAGR 2021-2025) of $10.1 \%$ resulting in a projected market volume of US $\$ 18,437 \mathrm{~m}$ by 2025 . As a result of this high demand, issues in the fashion industry occur, such as the problem of waste from 
fashion manufacturing polluting the environment. This subject has now become a global social issue. This is the point at which organic fashion started to gain popularity among the general public. The organic market fashion itself grows from the nook market to a stand-alone brand fashion; the market of this ethical fashion is expected to be $0.4 \%$ of the total market in the fashion industry and still growing till now (Globenewswire, 2020).

There are various kinds of fashion products and one of them is organic clothing products. Organic clothes are clothes that mainly use organic fabrics that are made of natural fibers using natural materials such as plant fibers and all chemical processes used are in accordance with the standards and meet the basic requirements for toxicity and biodegradability / eliminability (Carey \& Cervellon, 2011). There are also many advantages of these organic clothes, such as having a fiber material that is softer, biodegradable, and safe for the environment. Organic clothes also greatly reduce the use of pesticides normally used on cotton trees which are susceptible to pests, resulting in frequent overuse of pesticides. This is very dangerous for the surrounding ecosystem.

However, in Indonesia, it seems like there are still people who do not use this organic clothing product because of the skepticism or they do not have adequate knowledge about organic clothing products. It indicates that some barriers occur to consumers, so they haven't used organic clothing. These green product barriers can be categorized into five categories, based on the Innovation Resistance Theory, such as usage, value, risk, image, and behavior (Kushwah et al., 2019).

\section{Literature Review}

\section{Innovation Resistance Theory (IRT Theory)}

Innovation Resistance Theory is a theory that says for every innovation there must be resistance. This theory offers that innovation resistance can be defined as behavior resulting from rational thinking and decision-making (Kaur et al., 2020). The use of innovation can encourage consumers to resist if it changes their lifestyle and status (Ram \& Sheth, 1989). This theory also applies to the purchase of organic products; since organic products are an innovation, there must be some opposition to them. Based on prior studies, this principle has been shown to be used in the sense of purchasing organic goods (Shafira \& Mayangsari, 2020). This research implements the innovation resistance theory that occurs in the purchase and use of organic fashion by consumers. Innovation resistance theory has proposed three functional barriers: usage, value, and risk barriers, and two psychological barriers: tradition barriers and image barriers (Kushwah et al., 2019).

\section{Usage Barrier}

The Usage barrier happens when a customer faces an innovation that is not compatible with existing experience, routines, or usages (Ram \& Sheth, 1989). The barriers, such as limited variety, availability, low visibility in the shop, inadequate information, and convenience, have a significant association with purchase intentions (Kushwah et al., 2019).

\section{Value Barrier}

Ram and Sheth, 1989 said that the value barrier refers to the success of innovation and its monetary value; if the innovation does not achieve anticipated performance-to-price compared to alternatives, customers would not be willing to change their consumption habits. When customers discover that the value of a new product is less than that of an existing alternative, value barriers emerge (Laukkanen et al., 2008). Align with that, many studies said that higher prices came out as the most crucial cause of consumer resistance toward organic products (Kushwah et al., 2019).

\section{Risk Barrier}


Every innovation has its own uncertainty and side effects that cannot be predicted therefore, customers who are aware of the risks try to put off adopting a new product until they have more information (Ram \& Sheth, 1989).

\section{Tradition Barrier}

The tradition barrier arises when an innovation causes a customer to alter their existing habits (Ram \& Sheth, 1989). Tradition barriers, such as satisfaction with non-organic products and a lack of awareness, prevent people from using organic products (Shafira \& Mayangsari, 2020). A consumer that feels content with the non-organic product will lack the requisite knowledge to make the transition to organic products (Botonaki et al., 2006).

\section{Image Barrier}

Image barriers may arise if these associations such as production, branding, or product variety are unfavorable and the customer develops an unfavorable image about the product (Ram and Sheth, 1989). Image barrier in the case of organic food refers to the overall image of this food product in general; for example, some consumers do not see any differences between organic and conventional food (Torres-Ruiz et al., 2018).

\section{Organic fashion}

Organic products are those that are produced without the use of pesticides, synthetic fertilizers, waste sludge, genetically modified organisms, or ionizing radiation, according to Organic.org (2010). Organic fashion uses organic fabrics that are made of natural fibers using natural materials such as plant fibers, and all chemical processes used are in accordance with the standards and meet the basic requirements for toxicity and biodegradability / eliminability (Carey \& Cervellon, 2011).

\section{Conceptual framework}

This research adopts the innovation resistance theory research framework used by (Kaur et al., 2020). The previous researcher used IRT to study the association of different functional (ie, value, usage, and risk) and psychological barriers (namely, tradition and image) with use intentions toward mobile payment systems and intention to recommend MPSs. However, this study will only reach the intention to buy and not the intention to recommend.

Figure 1: Conceptual Framework

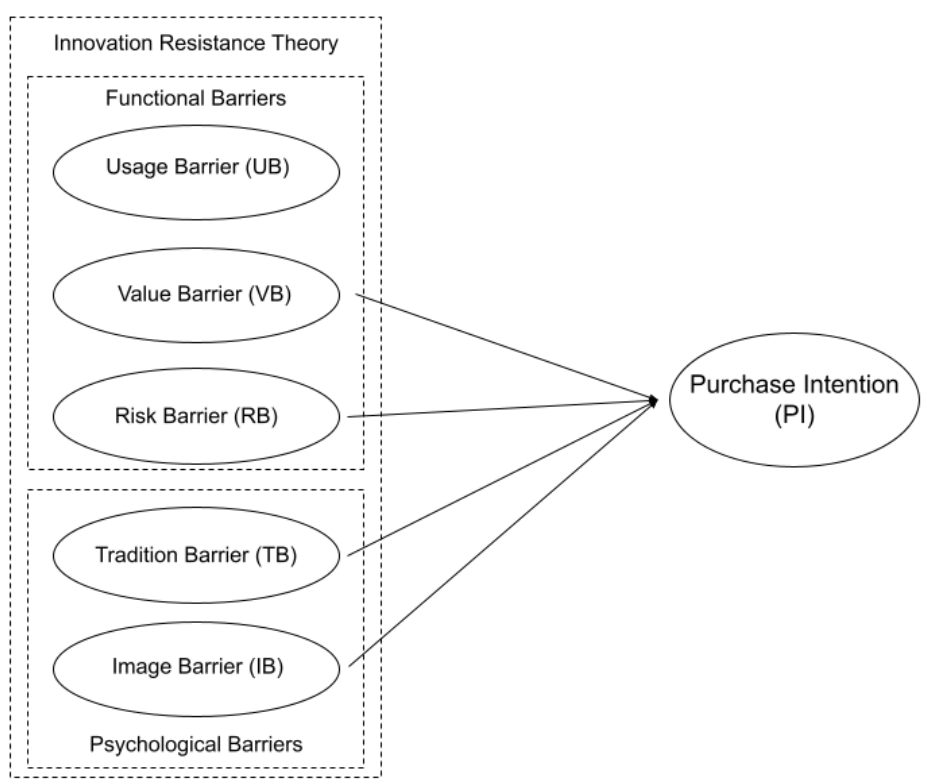


Based on the literature review, the hypothesis are:

H1: Usage barriers significantly influence purchase intention of organic clothing products.

$\mathrm{H} 2$ : Value barriers significantly influence purchase intention of organic clothing products.

H3: Risk barriers significantly influence purchase intention of organic clothing products.

$\mathrm{H} 4$ : Tradition barriers significantly influence purchase intention of organic clothing products.

H5: Image barriers significantly influence purchase intention of organic clothing products.

\section{Research Method}

The researcher used a quantitative approach with survey analysis. According to Sugiyono (2010), survey analysis is data collection through questionnaires. The data was collected using a survey by questioning respondents about the barrier towards organic fashion. This study also uses Multiple Linear Regression as the statistical technique to analyze the influence of innovation resistance of organic clothing products towards consumers' intention to buy.

\section{Population}

This study's population is Indonesian women in the $\mathrm{Z}$ generation focused on the ones living in Jabodetabek and Bandung as a metropolitan city that has a tendency to know about organic products but rarely using organic clothing products.

\section{Sampling Procedure}

The researcher chose to use non-probability sampling, with a purposive sampling technique with the main goal to generate a sample that can reasonably be believed to be representative of the population (Courser \& Lavrakas, 2012). The sample size is the total respondents included in this study. At least 5 observations are required for each projected parameter (Anderson et al., 1992), or 5 respondents are required for each item observation. Therefore this study has 32 item observations so we can conclude that researcher need 160 respondents of women in the $\mathrm{z}$ generations.

\section{Data Collection}

This research will consist of two-part, the introduction part and the main part. The introduction part will consist of the socio-demographic data about respondents that consisted of gender, age, current domicile, and occupation. The main part will consist of the independent variable which is the consumption barriers of organic fashion products. This research used a 5-point Likert scale, a psychometric scale, to determine the respondents' preferences based on statements of psychological measures. One was designated as strongly disagree, two was designated as disagree, three was designated as undecided or neutral, four was designated as agree, and five was designated as strongly agree. The researcher has used a Google Form to create a questionnaire online with Indonesia language as the base language because the limitation area of this study is in Indonesia. As for the communication, the researcher distributed the questionnaire using the social media Line via personal chat and Instagram via direct message.

\section{Data Analysis}

This study using Statistical Package for the Social Sciences. SPSS is a statistical package for the social sciences (SPSS) to to collect and analyze all of the information gathered. This research uses multiple linear regression as the statistical technique that will analyze the relationship between a single dependent variable and several independent variables (Hair, et al. 2009). Before we do the multiple linear regression, the data have to pass the classical assumption. Which consist of normality test, heteroscedasticity test, multicollinearity test, and linearity test. 


\section{Result}

\section{Descriptive analysis}

The primary data used in this study was obtained from an online questionnaire using Google Forms as tools. The questionnaire was distributed to respondents who met the criteria. In this study, 166 respondents were gathered from a minimum requirement of 135 respondents. All of the respondents are women in generation Z- with ages ranging from 16 to 25 years old. There were 60 out of 166 respondents aged 21 years old, 38 out of 166 respondents aged 20 years old, and 32 respondents aged 22 years old. The remaining members are aged 17, 18, 19, 23, 24, and 25. The majority of respondents (53.6\%) live in Jakarta or Bandung (46.4\%).

\section{Validity and Reliability}

\section{Validity}

If the value of calculated $R$ is greater than the value of the item's $R$ table, the item is considered valid. The $\mathrm{R}$ table for 166 data in this test is 0.151 . According to the results, all of the items passed the validity test.

\section{Reliability}

Cronbach's Alpha was used as a reliability estimator by the author. Cronbach alpha of 0.6 is considered acceptable. There are seven questions used to represent the usage barrier the Cronbach alpha score is 0.772 , eight questions used to represent value barrier the Cronbach alpha score is 0.668 , four questions used to represent risk barrier the Cronbach alpha 0.641 , five questions to represent tradition barrier the Cronbach alpha score is 0.753 , three questions used to represent image barrier the Cronbach alpha score is 0.723 , and six questions used to represent purchase intention the Cronbach alpha score is 0.874 . Based on the test result, all of the items passed the reliability test so we can continue the process.

\section{Classical Assumption}

\section{Normality Test}

The Kolmogorov-Smirnov test was used to determine whether the data was normal. According to the table above, the raw Asymp.sig.(2-tailed) significance value is 0.200 , which is greater than 0,05 . As a result, we can conclude that the data is normally distributed and that the data passed the normality test based on the result.

Table 1: Normality Test

\begin{tabular}{|c|c|c|}
\hline \multicolumn{3}{|r|}{ Test } \\
\hline & & $\begin{array}{l}\text { Unstandardiz } \\
\text { ed Residual }\end{array}$ \\
\hline \multicolumn{2}{|l|}{$\mathrm{N}$} & 166 \\
\hline \multirow[t]{2}{*}{ Normal Parameters ${ }^{a, b}$} & Mean & .0000000 \\
\hline & Std. Deviation & 4.14369566 \\
\hline \multirow[t]{3}{*}{ Most Extreme Differences } & Absolute & .043 \\
\hline & Positive & .035 \\
\hline & Negative & -.043 \\
\hline \multicolumn{2}{|l|}{ Test Statistic } & .043 \\
\hline \multicolumn{2}{|l|}{ Asymp. Sig. (2-tailed) } & $.200^{\mathrm{c}, \mathrm{d}}$ \\
\hline \multicolumn{3}{|c|}{ a. Test distribution is Normal. } \\
\hline \multicolumn{3}{|l|}{ b. Calculated from data. } \\
\hline \multicolumn{3}{|c|}{ c. Lilliefors Significance Correction. } \\
\hline \multicolumn{3}{|c|}{ d. This is a lower bound of the true significance. } \\
\hline
\end{tabular}




\section{Heteroscedasticity and Multicollinearity Test}

The researcher used tolerance and VIF values from each independent variable to test multicoreliance. There is no multicollinearity if the data has a tolerance value of more than 0.1 and a VIF value of less than 10. (Anderson et al., 1992). Based on the table, we can conclude that there is no multicollinearity and the data passed the multicollinearity test because all tolerance values are above 0.1 and VIF values are below 10. The Glejser method is used. All independent variables have a significance level of greater than 0.05. It means that the data is homogeneous and there is no heterogeneity in it. As a result, the heterogeneity test was passed on this data.

\section{Coefficients $^{a}$}

\begin{tabular}{|c|c|c|c|c|c|c|}
\hline \multirow[b]{2}{*}{ Mode } & & \multicolumn{2}{|c|}{ Unstandardized Coefficients } & \multirow{2}{*}{$\begin{array}{c}\begin{array}{c}\text { Standardized } \\
\text { Coefficients }\end{array} \\
\text { Beta }\end{array}$} & \multirow[b]{2}{*}{$\mathrm{t}$} & \multirow[b]{2}{*}{ Sig. } \\
\hline & & $B$ & Std. Error & & & \\
\hline \multirow[t]{6}{*}{1} & (Constant) & .407 & 1.488 & & .273 & .785 \\
\hline & UB & .094 & .060 & .154 & 1.563 & .120 \\
\hline & VB & -.100 & 061 & -.150 & -1.641 & 103 \\
\hline & RB & .186 & .088 & 186 & 2.117 & .036 \\
\hline & TB & .042 & .077 & .053 & .554 & .580 \\
\hline & IB & .005 & .096 & .005 & .054 & .957 \\
\hline
\end{tabular}

a. Dependent Variable: Abs_RES

\begin{tabular}{|c|c|c|c|c|c|c|c|c|}
\hline \multicolumn{9}{|c|}{ Coefficients $^{a}$} \\
\hline \multirow[b]{2}{*}{ Mode } & & \multicolumn{2}{|c|}{ Unstandardized Coefficients } & \multirow{2}{*}{$\begin{array}{c}\begin{array}{c}\text { Standardized } \\
\text { Coefficients }\end{array} \\
\text { Beta }\end{array}$} & \multirow[b]{2}{*}{$\mathrm{t}$} & \multirow[b]{2}{*}{ Sig. } & \multicolumn{2}{|c|}{ Collinearity Statistics } \\
\hline & & B & Std. Error & & & & Tolerance & VIF \\
\hline \multirow[t]{6}{*}{1} & (Constant) & 15.913 & 2.547 & & 6.249 & .000 & & \\
\hline & UB & .106 & .103 & .099 & 1.026 & .306 & .599 & 1.670 \\
\hline & VB & -.022 & .104 & -.019 & -.212 & .832 & .694 & 1.441 \\
\hline & RB & .452 & .150 & .260 & 3.015 & .003 & .748 & 1.337 \\
\hline & TB & -.414 & .131 & -.294 & -3.158 & .002 & .643 & 1.556 \\
\hline & IB & .268 & .164 & .135 & 1.632 & .105 & .808 & 1.237 \\
\hline
\end{tabular}

a. Dependent Variable: PI

\section{Linearity Test}

The researcher uses Deviation from Linearity sig. score. If the deviation from linearity sig. $>0.05$, then there is a significant linear relationship between the independent variable and the dependent variable. Based on the results of the table above, all significant values of deviation from linearity for each variable in sequence are $0.931,0.432,0.538,0.536$ and 0.348 , which means it is greater than 0.05 . So, it can be concluded that there is a significant linear relationship between the independent variables (Usage barrier, Value barrier, Risk barrier, Tradition Barrier, Image barrier) and the dependent variable (Purchase Intention). 


\begin{tabular}{|c|c|c|c|c|c|c|c|}
\hline \multicolumn{8}{|c|}{ ANOVA Table } \\
\hline & & & $\begin{array}{l}\text { Sum of } \\
\text { Squares }\end{array}$ & df & Mean Square & $\mathrm{F}$ & Sig. \\
\hline \multirow[t]{5}{*}{$\mathrm{PI}^{*} \mathrm{UB}$} & Between Groups & (Combined) & 1709.887 & 102 & 16.764 & .719 & .931 \\
\hline & & Linearity & 17.523 & 1 & 17.523 & .752 & .389 \\
\hline & & Deviation from Linearity & 1692.364 & 101 & 16.756 & .719 & .931 \\
\hline & Within Groups & & 1467.906 & 63 & 23.300 & & \\
\hline & Total & & 3177.794 & 165 & & & \\
\hline \multicolumn{8}{|c|}{ ANOVA Table } \\
\hline & & & $\begin{array}{l}\text { Sum of } \\
\text { Squares }\end{array}$ & df & Mean Square & $\mathrm{F}$ & Sig. \\
\hline \multirow{5}{*}{$\mathrm{PI}^{*} \mathrm{VB}$} & Between Groups & (Combined) & 2495.738 & 128 & 19.498 & 1.058 & .436 \\
\hline & & Linearity & 13.237 & 1 & 13.237 & .718 & .402 \\
\hline & & Deviation from Linearity & 2482.501 & 127 & 19.547 & 1.060 & .432 \\
\hline & Within Groups & & 682.056 & 37 & 18.434 & & \\
\hline & Total & & 3177.794 & 165 & & & \\
\hline \multicolumn{8}{|c|}{ ANOVA Table } \\
\hline & & & $\begin{array}{l}\text { Sum of } \\
\text { Squares }\end{array}$ & df & Mean Square & $\mathrm{F}$ & Sig. \\
\hline \multirow[t]{5}{*}{$\mathrm{PI}{ }^{*} \mathrm{RB}$} & Between Groups & (Combined) & 976.676 & 47 & 20.780 & 1.114 & .316 \\
\hline & & Linearity & 145.852 & 1 & 145.852 & 7.819 & .006 \\
\hline & & Deviation from Linearity & 830.824 & 46 & 18.061 & .968 & .538 \\
\hline & Within Groups & & 2201.117 & 118 & 18.654 & & \\
\hline & Total & & 3177.794 & 165 & & & \\
\hline \multicolumn{8}{|c|}{ ANOVA Table } \\
\hline & & & $\begin{array}{l}\text { Sum of } \\
\text { Squares }\end{array}$ & df & Mean Square & $\mathrm{F}$ & Sig. \\
\hline \multirow[t]{5}{*}{$P I^{\star}{ }^{2} \mathrm{~TB}$} & Between Groups & (Combined) & 1105.040 & 58 & 19.052 & .984 & .519 \\
\hline & & Linearity & 29.483 & 1 & 29.483 & 1.522 & .220 \\
\hline & & Deviation from Linearity & 1075.557 & 57 & 18.869 & .974 & .536 \\
\hline & Within Groups & & 2072.753 & 107 & 19.372 & & \\
\hline & Total & & 3177.794 & 165 & & & \\
\hline \multicolumn{8}{|c|}{ ANOVA Table } \\
\hline & & & $\begin{array}{l}\text { Sum of } \\
\text { Squares }\end{array}$ & df & Mean Square & $\mathrm{F}$ & Sig. \\
\hline \multirow[t]{5}{*}{$\mathrm{PI} * \mathrm{IB}$} & Between Groups & (Combined) & 494.167 & 22 & 22.462 & 1.197 & .260 \\
\hline & & Linearity & 57.960 & 1 & 57.960 & 3.088 & .081 \\
\hline & & Deviation from Linearity & 436.208 & 21 & 20.772 & 1.107 & .348 \\
\hline & Within Groups & & 2683.626 & 143 & 18.767 & & \\
\hline & Total & & 3177.794 & 165 & & & \\
\hline
\end{tabular}

\section{Multiple Linear Regression}

\section{F-Test}

The F-test is used in this study to determine whether independent variables influence dependent variables synchronously. According to Ghozali (2011), Independent variables influence dependent variables if the F-value is greater than the F-Table and the significance is less than 0.05 . From the result, the F-table score is 2.27 and the F-value score is 3.89 , which means the F-value score is greater than the F-table score. The significance value is 0.002 which is less than 0.05 . So, we can conclude that the independent variables (Usage Barrier, Value Barrier, Risk Barrier, Tradition Barrier, and Image Barrier) simultaneously influence the dependent variable (Purchase Intention).

Table 5: F-Test

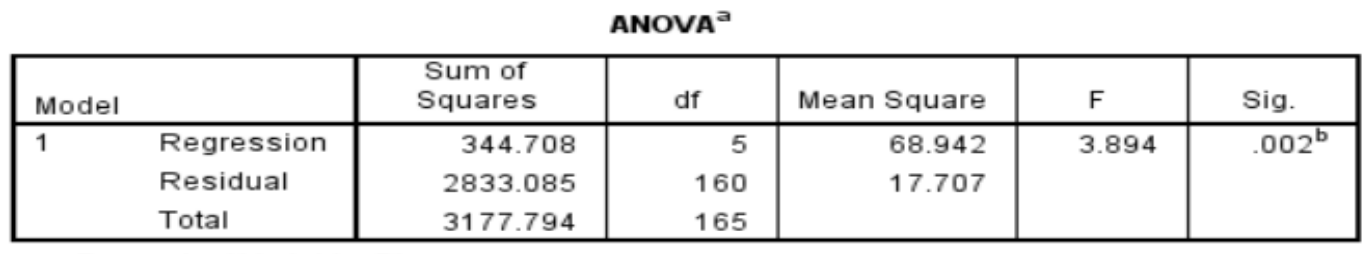

a. Dependent Variable: PI

b. Predictors: (Constant), IB, UB, RB, VB, TB 


\section{T-Test}

The T-test is used to determine the impact of independent variables (usage barrier, value barrier, risk barrier, tradition barrier, and image barrier) on the dependent variable (purchase intention) both individually and partially. The significance values 0.05 and $\mathrm{T}-$ values $>\mathrm{t}$-table indicate that the independent variables are simultaneously influencing the dependent variables (Ghozali, 2011). Based on the result, the t-table of this research is 1.9744 . According to the table above) the independent variables that have a significant value $<0.05$ are Risk Barrier (RB) which scores 0.003 and Tradition Barrier (TB) which score 0.002. Then, the T-value of both Risk Barrier (RB) and Tradition Barrier (TB) are respectively 3.015 and -3.158 . Because Risk Barrier (RB and Tradition Barrier (TB) have significance value $<0.05$ and the score of T-value $>\mathrm{T}$ table (1.9732), we can conclude that risk barrier and tradition barrier influence women in the gen-z intention to purchase organic clothes, whereas value barrier (VB), usage barrier (UB), and image barrier do not significantly influence woman gen $\mathrm{z}$ purchase intention because of the $\mathrm{T}$-value $>\mathrm{T}$-table and the significant value $>0.05$.

Table 6: T-Test

\section{Coefficients $^{\mathrm{a}}$}

\begin{tabular}{|c|c|c|c|c|c|c|}
\hline \multirow{2}{*}{\multicolumn{2}{|c|}{ Model }} & \multicolumn{2}{|c|}{ Unstandardized Coefficients } & \multirow{2}{*}{$\begin{array}{c}\text { Standardized } \\
\text { Coefficients } \\
\text { Beta } \\
\end{array}$} & \multirow[b]{2}{*}{$\mathrm{t}$} & \multirow[b]{2}{*}{ Sig. } \\
\hline & & $B$ & Std. Error & & & \\
\hline \multirow[t]{6}{*}{1} & (Constant) & 15.913 & 2.547 & & 6.249 & .000 \\
\hline & UB & .106 & .103 & .099 & 1.026 & .306 \\
\hline & VB & -.022 & .104 & -.019 & -.212 & .832 \\
\hline & RB & .452 & .150 & .260 & 3.015 & .003 \\
\hline & TB & -.414 & .131 & -.294 & -3.158 & .002 \\
\hline & IB & .268 & .164 & .135 & 1.632 & .105 \\
\hline
\end{tabular}

a. Dependent Variable: PI

Based on the beta score in the table, the regression equation is:

- $\mathrm{PI}=15.913+0.452(\mathrm{RB})-0.414(\mathrm{~TB})$

○ PI: Purchase Intention

○ RB: Risk Barrier

$\circ$ TB: Tradition Barrier

\section{Hypothesis Testing}

According to the analysis of the T-test, we can conclude that of the five independent variables, only two of the variables significantly influence the women in generation $\mathrm{z}$ purchase intention of organic clothing products, which is risk barrier and tradition barrier.

Table 7: Hypothesis Testing

\begin{tabular}{llll}
\hline Code & Hypothesis & Result & Conclusion \\
\hline H1 & $\begin{array}{l}\text { Usage barriers significantly influence Purchase } \\
\text { intention of Organic clothing products. }\end{array}$ & Not significant & Not supported \\
H2 & $\begin{array}{l}\text { Value barriers significantly influence Purchase } \\
\text { intention of Organic clothing products. }\end{array}$ & Not significant & Not supported \\
H3 & $\begin{array}{l}\text { Risk barriers significantly influence Purchase } \\
\text { intention of Organic clothing products. }\end{array}$ & Significant & Supported \\
\hline
\end{tabular}




\section{$\mathrm{H} 4$}

H5
Tradition barriers significantly influence Purchase intention of Organic clothing products.
Significant

Image barriers significantly influence Purchase intention of Organic clothing products.
Not significant Not supported
Supported

\section{Discussion}

Using innovation resistance theory as the barrier of the organic clothing line, the researcher found five barriers of new innovation which are usage barrier, value barrier, risk barrier, tradition barrier, and image barrier. So, the researcher has five hypotheses. The first one from H1, Usage barriers significantly influence Purchase intention of Organic clothing products. According to Nandi, et al. (2016) the factor of limited variety or poor range of organic products and its unavailability in the market can be the reason why customers are not purchasing organic products. But, in this research, the hypothesis is rejected because of the sig. Value is greater than 0.05 and the T-value score is $1.026<\mathrm{T}$ table. It means that the usage barrier does not significantly influence the barrier of organic clothing product purchase intention.

From H2, Value barriers significantly influence the Purchase intention of Organic clothing products. Value barriers consist of several constructs that are mainly about price, quality, and benefit (Kotler, 2009). The hypothesis is rejected because of the sig. Value is greater than 0.05 and the T-value score is $-0,212<\mathrm{T}$-table. It means that the value barrier does not significantly influence the barrier of organic clothing product purchase intention and the respondents in this research do not mind the price as long as it is balanced with the benefits and quality.

From H3, Risk barriers significantly influence the Purchase intention of Organic clothing products. Risk barriers can arise as a result of a lack of trust in stakeholders, as well as doubts about the certification of organic products or doubts about the user's knowledge (Khrisna \& Balasubramanian, 2018). This means that customers need to feel secure with the amount of knowledge that they have and have clear certification and labeling from the product. This hypothesis is accepted because of the sig. Value is less than 0.05 and the T-value score is $3.015>\mathrm{T}$-table. This means that the risk barrier has a significant influence on the barrier of organic clothing product purchase intention, and customers have doubts about purchasing this organic clothing product.

From H4, Tradition barriers significantly influence Purchase intention of Organic clothing products. Tradition barriers arise when an innovation causes a customer to alter their existing habits (Ram \& Sheth, 1989). In addition to tradition barrier, it also includes the lack of knowledge of the product itself (Hoppe, Vieira, \& Barcellos, 2013). The statement is proved with H4 is accepted, in this research, the significance value for $\mathrm{H} 4$ is less than 0.05 and the $\mathrm{t}$-value score is $-3.158>\mathrm{t}$-table. It means, tradition barriers are significantly influencing the barriers of organic clothing product consumption.

From H5, Image barriers significantly influence Purchase intention of Organic clothing products. Image barriers may arise if these associations such as production, branding, or product variety are unfavorable and the customer develops an unfavorable image about the product (Ram \& Sheth, 1989). Customers can feel skeptical against organic clothing products that have no different from conventional ones. But this statement is not in accordance with the result of this research because H5 is rejected. The significance value of $\mathrm{H} 5$ is greater than 0.05 and the t-value score is 1.632 which is less than the t-table. It means that the image barrier does not significantly influence the barrier of organic clothing product purchase intention. 


\section{Conclusion}

Within this study, the researchers tried to analyze the barriers to purchasing organic clothing products. Using innovation resistance theory as the barrier of the organic clothing line, the researcher found five barriers of new innovation which are usage barrier, value barrier, risk barrier, tradition barrier, and image barrier. The data is collected using an online survey by spreading the questionnaire to 166 respondents with a specific region in Jabodetabek and Bandung. The data is later analyzed using SPSS with clustering analysis and multiple linear regression.

The objective of this research is to seek which barrier that influences the purchase intention of consumers towards organic clothing products. The researcher conducts multiple linear regression to analyze it and found that risk barrier and tradition barrier significantly influence the purchase intention. This statement is also supported by Laukkanen et. al (2008) who stated in his research that risk barrier, image barrier, and tradition barrier are the most intense barrier, but in this research, image barrier does not significantly influence the purchase intention.

In this research, there is indeed a slide effect, a sufficient relationship between the independent variable and the dependent variable. But we have to consider other aspects, if the situation did not disrupt by pandemic the result of this study is more significant, including the independent variable that is being used as predictors of someone's resistance towards purchase intention of the organic clothing line. The results of this study can only be generalized in a limited scope and there needs to be another approach to generalize it more broadly using different methods. This study also has limitations on the scale of the population that is difficult to identify, which is people who know about organic products but rarely buy organic clothing products, so the researcher ended up using the intersection of required characteristics and purposive sampling. This study only looks at barriers and purchase intentions. Recommendation for further research, if the researcher wants to analyze the market with this pandemic condition, it is better if the researcher uses an exploratory research approach and tries another method that is more effective than explanatory research. There is also a good chance that the researcher will test variables other than barriers associated with organic clothing products.

\section{References}

Aitken, R., Watkins, L., Williams, J., \& Kean, A. (2020). The positive role of labelling on consumers' perceived behavioural control and intention to purchase organic food. Journal of Cleaner Production, 255, 120334. https://doi.org/10.1016/j.jclepro.2020.120334

Bassiouni, D. H., \& Hackley, C. (2014). Generation Z' Children's Adaptation to Digital Consumer Culture: A Critical Literature Review. Journal of Costumers Behavior, 13.

Botonaki, A., Polymeros, K., Tsakiridou, E., \& Mattas, K. (2006). The role of food quality certification on consumers' food choices. British Food Journal, 108(2), 77-90. https://doi.org/10.1108/00070700610644906

Cervellon, M.C., Wernerfelt, A.S. (2012). Knowledge sharing among green fashion communities online: Lessons for the sustainable supply chain. J. Fash. Mark. Manag., 16, 176-192. https://doi.org/10.1108/1361202121122286

Courser, M. W., \& Lavrakas, P. J. (2012). Item-Nonresponse and the 10-Point Response scale in telephone surveys. Survey Practice, 5(4), 1-5. https://doi.org/10.29115/sp-2012-0021

Ellis, J. L., McCracken, V. A., \& Skuza, N. (2012). Insights into willingness to pay for organic cotton apparel. Journal of Fashion Marketing and Management: An International Journal, 16(3), 290305. https://doi.org/10.1108/13612021211246053

Gam, H. J., Cao, H., Farr, C., \& Kang, M. (2010). Quest for the eco-apparel market: A study of mothers' willingness to purchase organic cotton clothing for their children. International Journal of Consumer Studies, 34(6), 648-656. https://doi.org/10.1111/j.14706431.2010.00898.x

Ghozali, I. (2011). Aplikasi Analisis Multivariate Dengan Program SPSS. Badan Penerbit Universitas Diponegoro. 
Gleim, M. R., Smith, J. S., Andrews, D., \& Cronin, J. J. (2013). Against the green: A multi-method examination of the barriers to green consumption. Journal of Retailing, 89(1), 44-61. https://doi.org/10.1016/j.jretai.2012.10.001

Hair, J. F., Black, W. C., Babin, B. J., \& Anderson, R. E. (2010). Multivariate data analysis: A global perspective. Pearson Education.

Hair, J.F., Black, W.C., Babin, B.J., Anderson, R.E. and Tatham, R.L., 1998. Multivariate data analysis. Upper Saddle River, NJ: Prentice hall

https://www.thebalancesmb.com/who-buys-organic-food-different-types-of-consumers-2538042. (Accessed on May 2021)

https://www.globenewswire.com/news-release/2020/10/28/2116073/0/en/Sustainable-Fashion-MarketAnalysis-Shows-The-Market-Progress-In-Attempt-To-Decrease-Pollution-In-The-GlobalEthicalfashion-Market-2020.html (Accessed on May 2021)

Kaur, P., Dhir, A., Singh, N., Sahu, G., \& Almotairi, M. (2020). An innovation resistance theory perspective on mobile payment solutions. Journal of Retailing and Consumer Services, 55, 102059. https://doi.org/10.1016/j.jretconser.2020.102059

Khare, A., \& Varshneya, G. (2017). Antecedents to organic cotton Clothing purchase behaviour: Study on Indian youth. Journal of Fashion Marketing and Management: An International Journal, 21(1), 51-69. https://doi.org/10.1108/jfmm-03-2014-0021

Kotler, Phiilip \& Keller, Kevin L. (2009). Marketing Management 13th Edition. New Jersey: Pearson Prentice Hall.

Kotler, P. \& Keller, K.L. (2009). Marketing management. 1. vyd. Praha: Grada, 2007, 788 s.

Kushwah, S., Dhir, A., Sagar, M., \& Gupta, B. (2019). Determinants of organic food consumption. a systematic literature review on motives and barriers. Appetite, 143, 104402. https://doi.org/10.1016/j.appet.2019.104402

Kushwah, S., Dhir, A., \& Sagar, M. (2019). Understanding consumer resistance to the consumption of organic food. A study of ethical consumption, purchasing, and choice behavior. Food Quality and Preference, 77, 1-14.

Laukkanen, P., Sinkkonen, S., \& Laukkanen, T. (2008). Consumer resistance to internet banking: Postponers, opponents and rejectors. International Journal of Bank Marketing, 26(6), 440-455. https://doi.org/10.1108/02652320810902451

Mandese, J. (1991). New study finds green confusion. Advertising Age, 62(45), 1-56.

Nandi, R., Bokelmann, W., Gowdru, N.V. \& Dias, G. (2017). Factors influencing consumers' willingness to pay for organic fruits and vegetables: Empirical evidence from a consumer survey in India. Journal of Food Products Marketing, 23(4), pp.430-451.

Nguyen, C., Nguyen, Y., Quy, T., City, C.M. (2020). Organic Foods: What Driving Factors of Intention? Are the Purchase, 13, 400-418.

Pham, T.H., Nguyen, T.N., Phan, T.T.H., Nguyen, N.T. (2019). Evaluating the purchase behaviour of organic food by young consumers in an emerging market economy. J. Strateg. Mark. 27, 540556. https://doi.org/10.1080/0965254X.2018.1447984

Ram, S., Sheth, J.N., (1989). Consumer resistance to innovations: The marketing problem and its solutions. J. Consum. Mark. 6, 5. https://doi.org/10.1108/EUM0000000002542

Torres-Ruiz, F.J., Vega-Zamora, M., Parras-Rosa, M. (2018). False barriers in the purchase of organic foods. The case of extra virgin olive oil in Spain. Sustain., 10, 1-14. https://doi.org/10.3390/su10020461

von Meyer-Höfer, M., Olea-Jaik, E., Padilla-Bravo, C.A., Spiller, A. (2015). Mature and Emerging Organic Markets: Modelling Consumer Attitude and Behaviour With Partial Least Square Approach. J. Food Prod. Mark., 21, 626-653. https://doi.org/10.1080/10454446.2014.949971

Wang, X., Pacho, F., Liu, J., Kajungiro, R. (2019). Factors influencing organic food purchase intention in Tanzania and Kenya and the moderating role of knowledge. Sustain, 11. https://doi.org/10.3390/su11010209

Yazdanpanah, M., Forouzani, M., \& Hojjati, M. (2015). Willingness of Iranian young adults to eat organic foods: Application of the health BELIEF Model. Food Quality and Preference, 41, 7583. https://doi.org/10.1016/j.foodqual.2014.11.012 